\title{
Application of Box-Behnken design in the optimisation of an on-line pre-concentration system using knotted reactor for cadmium determination by flame atomic absorption spectrometry ${ }^{\text {th }}$
}

\author{
Anderson S. Souza ${ }^{a, b}$, Walter N.L. dos Santos ${ }^{a}$, Sérgio L.C. Ferreira ${ }^{a, *}$ \\ ${ }^{a}$ Universidade Federal da Bahia, Instituto de Química, Núcleo de Excelência em Química Analítica da Bahia, \\ Campus Universitário de Ondina, Salvador, Bahia 40170-290, Brazil \\ ${ }^{\mathrm{b}}$ Universidade Estadual do Sudoeste da Bahia, Departamento de Química e Exatas, Campus de Jequié, Jequié, Bahia 45206-190, Brazil
}

Received 16 September 2004; accepted 19 January 2005

Available online 2 April 2005

\begin{abstract}
The present paper proposes an on-line pre-concentration system for cadmium determination in drinking water using flame atomic absorption spectrometry (FAAS). Cadmium(II) ions are retained as 1-(2-pyridylazo)-2-naphthol (PAN) complex at the walls of a knotted reactor, followed of elution using hydrochloric acid solution. The optimization was performed in two steps using factorial design for preliminary evaluation and a Box-Behnken design for determination of the critical experimental conditions. The variables involved were: sampling flow-rate, reagent concentration, $\mathrm{pH}$ and buffer concentration, and as response the analytical signal (absorbance). The validation process was performed considering the parameters: linearity and other characteristics of the calibration curve, analytical features of on-line pre-concentration system, precision, effect of other ions in the pre-concentration system and accuracy. Using the optimized experimental conditions, the procedure allows cadmium determination with a detection limit $(3 \sigma / \mathrm{S})$ of $0.10 \mu \mathrm{g} \mathrm{L}-1$, a quantification limit $(10 \sigma / \mathrm{S})$ of $0.33 \mu \mathrm{g} \mathrm{L}^{-1}$, and a precision, calculated as relative standard deviation (RSD) of $2.7 \%(n=7)$ and $2.4 \%(n=7)$ for cadmium concentrations of 5 and $25 \mu \mathrm{g} \mathrm{L}^{-1}$, respectively. A pre-concentration factor of 18 and a sampling frequency of $48 \mathrm{~h}^{-1}$ were obtained. The recovery for cadmium in the presence of several ions demonstrated that this procedure could be applied for the analysis of water samples. The method was applied for cadmium determination in drinking water samples collected in Salvador City, Brazil. The cadmium concentrations found in five samples were lower than the maximum permissible levels established by the World Health Organization.
\end{abstract}

(C) 2005 Elsevier B.V. All rights reserved.

Keywords: Multivariate optimisation; Cadmium; Knotted reactor; On-line preconcentration; Cd; Optimization; Knotted-reactor; Flame AAS

\section{Introduction}

Multivariate techniques have been used increasingly for the optimization of analytical methods over the past years [1-4]. They might be used for preliminary evaluation of experimental factors in analytical processes and/or for the

\footnotetext{
* This paper was presented at the 8th Rio Symposium on Atomic Spectrometry, held in Paraty, RJ, Brazil, 1-6 August 2004, and is published in the special issue of Spectrochimica Acta Part B, dedicated to that conference.

* Corresponding author.

E-mail address: slcf@ufba.br (S.L.C. Ferreira).
}

determination of critical conditions (maximum or minimum) of these factors [5,6]. For preliminary evaluation, the two-level factorial design has been used, and response surface methodologies are applied for the determination of critical conditions, because these techniques use factors with more than three levels, and this way they can establish quadratic models. Central composite [5,6], BoxBehnken [5-7] and Doehlert designs [5-7] are among the principal response surface methodologies used in experimental design.

Box-Behnken design requires an experiment number according to $N=k^{2}+k+c_{\mathrm{p}}$, where $(k)$ is the factor number and $\left(c_{\mathrm{p}}\right)$ is the replicate number of the central point. The 
same number of experiments is necessary for the Doehlert matrix. The central composite design requires a greater number of experiments, which is calculated according to $N=k^{\mathrm{k}}+2 k+c_{\mathrm{p}}$, where $(k)$ is the variable number and $\left(c_{\mathrm{p}}\right)$ is the number of central points [7]. Box-Behnken is a spherical, revolving design. Viewed as a cube (Fig. 1a), it consists of a central point and the middle points of the edges. However, it can also be viewed as consisting of three interlocking $2^{2}$ factorial designs and a central point (Fig. 1b) [5]. It has been applied for optimization of several chemical and physical processes [8-10]; however, its application in analytical chemistry is much smaller than the central composite and Doehlert matrix designs [11]. In analytical chemistry, it was used for optimization of separation process of several amino-acid hydroxamates [12], experimental conditions in gas chromatography mass spectrometry method for the analysis of aminoglycoside antibiotics [13], a procedure for pararosaniline determination of formaldehyde [14], and optimization of conditions for an automatic pre-concentration system for lead determination in water [15].

The quality control of drinking water is a world concern and several chemical species should be rigorously con-

a)

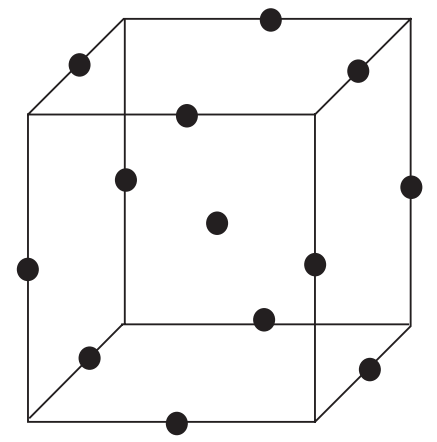

b)

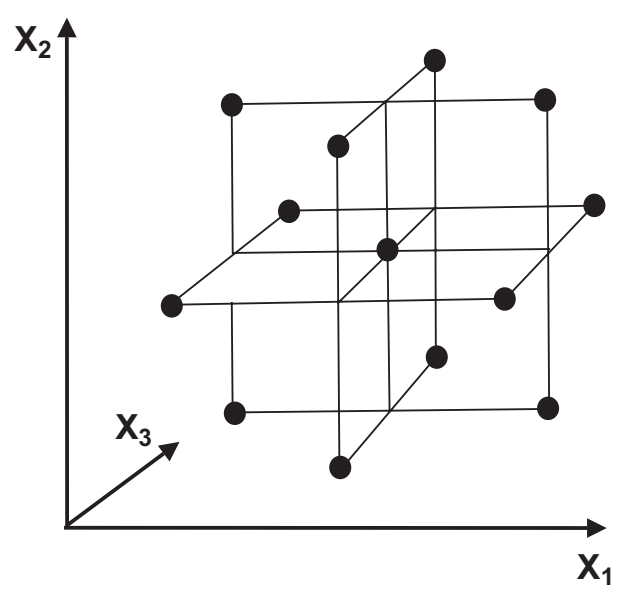

Fig. 1. Box-Behnken design. a.) The design, as derived from a cube; b.) Representation as interlocking $2^{2}$ factorial experiments. trolled [16,17]. Among these, some heavy metals such as lead and cadmium are most critical. Several methods have been developed including pre-concentration procedures $[18,19]$ considering that the detection limits of the main spectroanalytical techniques, flame atomic absorption spectrometry (FAAS) and inductively coupled plasma optical emission spectrometry (ICP OES), are not compatible with a direct determination of these metals in drinking water.

On-line pre-concentration systems using knotted reactors have been widely used for metal determination using spectroanalytical techniques. These enrichment procedures are based in the adsorption of hydrophobic complexes of metal ions on the walls of the knotted reactors, followed by an elution step using acid solutions [20]. Methods using FAAS [21,22], ICP OES $[23,24]$, graphite furnace atomic absorption spectrometry $[25,26]$ and inductively coupled plasma mass spectrometry $[27,28]$ have been proposed for the analysis of several samples.

In this paper, an on-line pre-concentration system using a knotted reactor was developed for cadmium determination in drinking water by FAAS, using (1-(2-pyridylazo)-2naphthol) PAN as complexing reagent. The experimental conditions of the system were established using factorial and Box-Behnken designs.

\section{Experimental}

\subsection{Instrumentation}

A Varian Model SpectrAA 220 (Mulgrave, Victoria, Australia) flame atomic absorption spectrometer was used for the analysis. The cadmium hollow cathode lamp was run under the conditions suggested by the manufacturer (current: $4.0 \mathrm{~mA})$. Also the wavelength $(228.8 \mathrm{~nm})$, the bandwidth of the slit $(0.5 \mathrm{~nm})$ and burner height $(13.5$ $\mathrm{mm}$ ) had conventional values. The flame composition was: acetylene (flow-rate $2.0 \mathrm{~L} \mathrm{~min}^{-1}$ ) and air (flow-rate: 13.5 $\mathrm{L} \mathrm{min}^{-1}$ ). Nebulizer flow-rates were 5.0-6.0 mL $\min ^{-1}$.

Two Alitea C-6 XV (Stockholm, Sweden) peristaltic pumps furnished with Tygon tubes were used to propel all solutions. A Rheodyne Model 5041 (Cotati, California, USA) four-way manual valve was used to select preconcentration/elution steps. All connections were made using fittings, unions and tees made of plastic and PEEK materials. The manifold was built up with PTFE tube of 0.5 $\mathrm{mm}$ bore. Knotted reactors (KR) were made by tying interlaced knots in $0.5 \mathrm{~mm}$ i.d., $1.5 \mathrm{~mm}$ o.d. and $1.5 \mathrm{~m}$ length of PTFE tubing as described in a previous paper [29]. The knots were made with about $5 \mathrm{~mm}$ diameter loops. They overlapped each other and care was taken to prevent constrictions in the conduit, which would impede the flow through the reactor. 


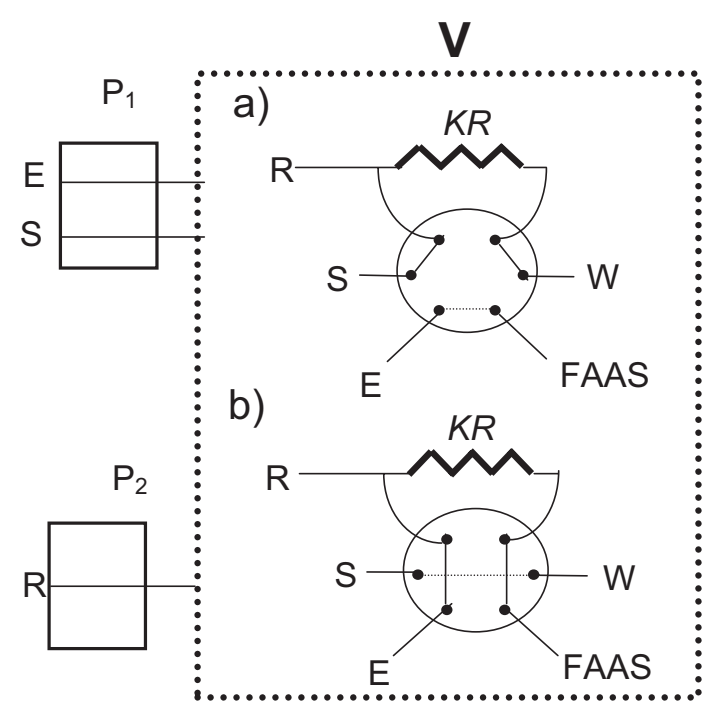

Fig. 2. Diagram of the pre-concentration system: a) Fill b) Inject. KR, Knotted Reactor; $\mathrm{P}_{1}, \mathrm{P}_{2}$, Peristaltic Pumps; R, Reagent; S, Sample; E, Eluent; W, Waste.

\subsection{Reagents}

All reagents were of analytical grade unless otherwise stated. Ultrapure water was obtained from an EASYpure RF purification system (Barnstedt, Dubuque, IA, USA). Nitric and hydrochloric acid were of Suprapur quality (Merck). Laboratory glassware was kept overnight in $10 \% \mathrm{v} / \mathrm{v}$ nitric acid solution, rinsed with deionized water and dried in dustfree environment.

Cadmium solution $\left(10.0 \mu \mathrm{g} \mathrm{mL} \mathrm{m}^{-1}\right.$ ) was prepared by diluting a $1000 \mu \mathrm{g} \mathrm{mL}^{-1}$ cadmium solution (Merck) with a $1 \% \mathrm{v} / \mathrm{v}$ hydrochloric acid solution.

PAN solution $\left(10^{-2} \mathrm{~mol} \mathrm{~L}^{-1}\right)$ was prepared by dissolving $0.25 \mathrm{~g}$ of 1-(2-Pyridylazo) 2-naphtol (PAN) in $100 \mathrm{~mL}$ of ethanol (Merck).

Tris buffer solution ( $\mathrm{pH} 8.3$ ) was prepared by dissolving $12.10 \mathrm{~g}$ of Tris-(hydroxymethyl) aminomethane (Merck) in $1000 \mathrm{ml}$ of deionized water and adjusting the $\mathrm{pH}$ with hydrochloric acid.

\subsection{Sample preparation}

The samples were filtered through $0.45 \mu \mathrm{m}$ membrane immediately after sampling, acidified to $\mathrm{pH} 2.0$ with nitric acid and stored at $6 \mathrm{C}$. The bottles were previously washed with a $10 \%(\mathrm{v} / \mathrm{v})$ nitric acid solution and afterward with ultrapure water.

\subsection{Pre-concentration step}

The water sample containing cadmium (flow-rate 10.0 $\mathrm{mL} \min ^{-1}$ ), and $10^{-4} \mathrm{~mol} \mathrm{~L}{ }^{-1} \mathrm{PAN}$ solution (flow-rate 2.7 $\mathrm{mL} \min ^{-1}$ ), buffered at $\mathrm{pH} 8.3$ with Tris buffer, were mixed on-line to form the metal complex. This mixture was loaded on the KR for $60 \mathrm{~s}$, valve $\mathrm{V}$ in load position (a) (Fig. 2).
Afterward, peristaltic pump $\mathrm{P}_{1}$ was stopped and the injection valve $\mathrm{V}$ switched to inject position (b), and the retained metal complex was eluted with $0.5 \mathrm{~mol} \mathrm{~L}^{-1}$ hydrochloric acid. The analytical signals (absorbance) were measured as peak height.

\subsection{Effect of other ions in the pre-concentration system}

This experiment was carried out using a multielement ICP OES solution Quality Control Standards (QCS-19), containing arsenic, antimony, beryllium, cadmium, calcium, chromium, cobalt, copper, iron, molybdenum, nickel, thallium, titanium, vanadium, zinc, lead, magnesium, manganese and selenium.

\subsection{Optimization strategy}

The optimization process was carried out using a full factorial design and a Box-Behnken design involving the variables: $\mathrm{pH}$, sampling flow-rate (SFR), buffer concentration (BC) and reagent concentration (RC) with absorbance as analytical response. The experimental data were processed using the STATISTICAL program. All experiments were carried out using $10.0 \mathrm{~mL}$ of cadmium solution of $10.0 \mu \mathrm{g} \mathrm{L}^{-1}$ concentration.

\section{Results and discussion}

\subsection{Determination of the experimental conditions of the on- line system}

On-line pre-concentration systems using knotted reactors can have many variables for optimization. Therefore, the factors: knotted reactor length, eluent concentration and eluent flow-rate were fixed in this system as being $150 \mathrm{~cm}$,

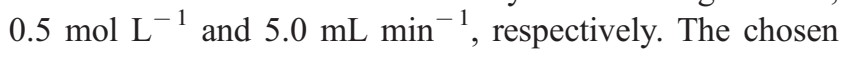
eluent was hydrochloric acid solution.

The optimization step was performed in two steps, involving the experimental factors: $\mathrm{pH}$, buffer concentration, reagent concentration and sampling flow-rate. Firstly a two-level factorial design $\left(2^{4}\right)$ was performed for these four variables. The level maximum and minimum for each factor are described in Table 1. The matrix of the factorial design and its results are shown in Table 2. The results of this design, as Pareto chart (Fig. 3) demonstrate that in the studied levels all these variables are statistically significant.

Table 1

Factors and levels used in the factorial design

\begin{tabular}{lll}
\hline Variable & Low $(-)$ & High $(+)$ \\
\hline Sampling flow-rate (SR) & $6.0 \mathrm{~mL} \mathrm{~min}^{-1}$ & $10.0 \mathrm{~mL} \mathrm{~min}^{-1}$ \\
Reagent concentration (RC) & $5 \times 10^{-5} \mathrm{~mol} \mathrm{~L}^{-1}$ & $20 \times 10^{-5} \mathrm{~mol} \mathrm{~L}^{-1}$ \\
pH & 7.0 & 9.0 \\
Buffer concentration (BC) & $0.01 \mathrm{~mol} \mathrm{~L}^{-1}$ & $0.03 \mathrm{~mol} \mathrm{~L}^{-1}$ \\
\hline
\end{tabular}


Table 2

Full factorial design

\begin{tabular}{|c|c|c|c|c|c|}
\hline Experiments $\mathrm{p}$ & $\mathrm{pH}$ & $\begin{array}{l}\text { Buffer } \\
\text { concentration } \\
(\mathrm{BC}) \\
\mathrm{mol} \mathrm{L}^{-1}\end{array}$ & $\begin{array}{l}\text { Reagent } \\
\text { concentration } \\
(\mathrm{RC}) \\
\mathrm{mol} \mathrm{L}^{-1}\end{array}$ & 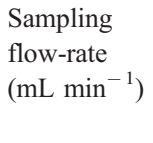 & $\begin{array}{l}\text { Response } \\
\text { (Absorbance) }\end{array}$ \\
\hline 1 & -1.0 & -1.0 & -1.0 & -1.0 & 0.06354 \\
\hline 2 & 1.0 & -1.0 & -1.0 & -1.0 & 0.02313 \\
\hline 3 & -1.0 & 1.0 & -1.0 & -1.0 & 0.05958 \\
\hline 4 & 1.0 & 1.0 & -1.0 & -1.0 & 0.02439 \\
\hline 5 & -1.0 & -1.0 & 1.0 & -1.0 & 0.05481 \\
\hline 6 & 1.0 & -1.0 & 1.0 & -1.0 & 0.01998 \\
\hline 7 & -1.0 & 1.0 & 1.0 & -1.0 & 0.04680 \\
\hline 8 & 1.0 & 1.0 & 1.0 & -1.0 & 0.01728 \\
\hline 9 & -1.0 & -1.0 & -1.0 & 1.0 & 0.06264 \\
\hline 10 & 1.0 & -1.0 & -1.0 & 1.0 & 0.02376 \\
\hline 11 & -1.0 & 1.0 & -1.0 & 1.0 & 0.06399 \\
\hline 12 & 1.0 & 1.0 & -1.0 & 1.0 & 0.02898 \\
\hline 13 & -1.0 & -1.0 & 1.0 & 1.0 & 0.06102 \\
\hline 14 & 1.0 & -1.0 & 1.0 & 1.0 & 0.01773 \\
\hline 15 & -1.0 & 1.0 & 1.0 & 1.0 & 0.04788 \\
\hline 16 & 1.0 & 1.0 & 1.0 & 1.0 & 0.01818 \\
\hline 17 & 0.0 & 0.0 & 0.0 & 0.0 & 0.03672 \\
\hline 18 & 0.0 & 0.0 & 0.0 & 0.0 & 0.03546 \\
\hline 19 & 0.0 & 0.0 & 0.0 & 0.0 & 0.03636 \\
\hline
\end{tabular}

Afterward, a Box-Behnken design was performed in order to determine the critical conditions. The variable sampling flow rate was fixed in the maximum level $\left(10.0 \mathrm{~mL} \mathrm{~min}^{-1}\right)$, considering also the results of the factorial design.

The experiments established in the Box-Behnken design for the variables: $\mathrm{pH}$, buffer concentration and reagent concentration are described in the Table 3 .

The relation among the variables (as coded values) $\mathrm{pH}$, buffer concentration (BC), reagent concentration (RC) and the analytical signal (AS) is fitted by the equation:

$$
\begin{aligned}
(\mathrm{AS})= & 0.05365+0.01304(\mathrm{pH})-0.001463(\mathrm{BC}) \\
& -0.002835(\mathrm{RC})-0.01170(\mathrm{pH})^{2} \\
& -0.008186(\mathrm{BC})^{2}-0.009604(\mathrm{RC})^{2}
\end{aligned}
$$

$$
\begin{aligned}
& +0.008753(\mathrm{pH})(\mathrm{BC})-0.009428(\mathrm{pH})(\mathrm{RC}) \\
& +0.004815(\mathrm{BC})(\mathrm{RC})
\end{aligned}
$$

The derivatization of this general equation as $(\mathrm{pH}),(\mathrm{RC})$ and $(\mathrm{BC})$ results in three new equations:

$$
\begin{aligned}
\delta(\mathrm{AS}) / \delta(\mathrm{pH})= & 0.01304-0.02340(\mathrm{pH})+0.008753(\mathrm{BC}) \\
& -0.009428(\mathrm{RC}) \\
\delta(\mathrm{AS}) / \delta(\mathrm{RC})= & -0.002835-0.009428(\mathrm{pH}) \\
& +0.004815(\mathrm{BC})-0.01921(\mathrm{RC}) \\
\delta(\mathrm{AS}) / \delta(\mathrm{BC})= & -0.001463+0.008753(\mathrm{pH}) \\
& -0.01637(\mathrm{BC})+0.004815(\mathrm{RC})
\end{aligned}
$$

This equation system shows an experimental condition for absorbance maximum in: $\mathrm{pH}$ (0.840), buffer concentration (0.211) and reagent concentration of $(-0.507)$. These results as coded values indicate real values of $\mathrm{pH}$ (8.34), buffer concentration $\left(0.011 \mathrm{~mol} \mathrm{~L}^{-1}\right)$ and reagent concentration of $\left(2.9710^{-5} \mathrm{~mol} \mathrm{~L}^{-1}\right)$.

Considering all these results, the conditions recommended for the method are: knotted reactor length $150 \mathrm{~cm}$, eluent concentration $0.5 \mathrm{~mol} \mathrm{~L}^{-1}$, eluent flow rate $5.0 \mathrm{~mL}$ $\min ^{-1}$, pH 8.3, buffer concentration $0.011 \mathrm{~mol} \mathrm{~L}^{-1}$ and reagent concentration $3 \cdot 0 \cdot 10^{-5} \mathrm{~mol} \mathrm{~L}^{-1}$.

\subsection{The effect of other ions in the pre-concentration system}

In order to check the effect of other ions, a standard solution containing cadmium and 18 other metal ions (each one at $10.00 \mu \mathrm{g} \mathrm{L}^{-1}$ ) was prepared and cadmium was determined using the proposed on-line pre-concentration system. The results showed that in this concentration, the other ions do not interfere in the cadmium

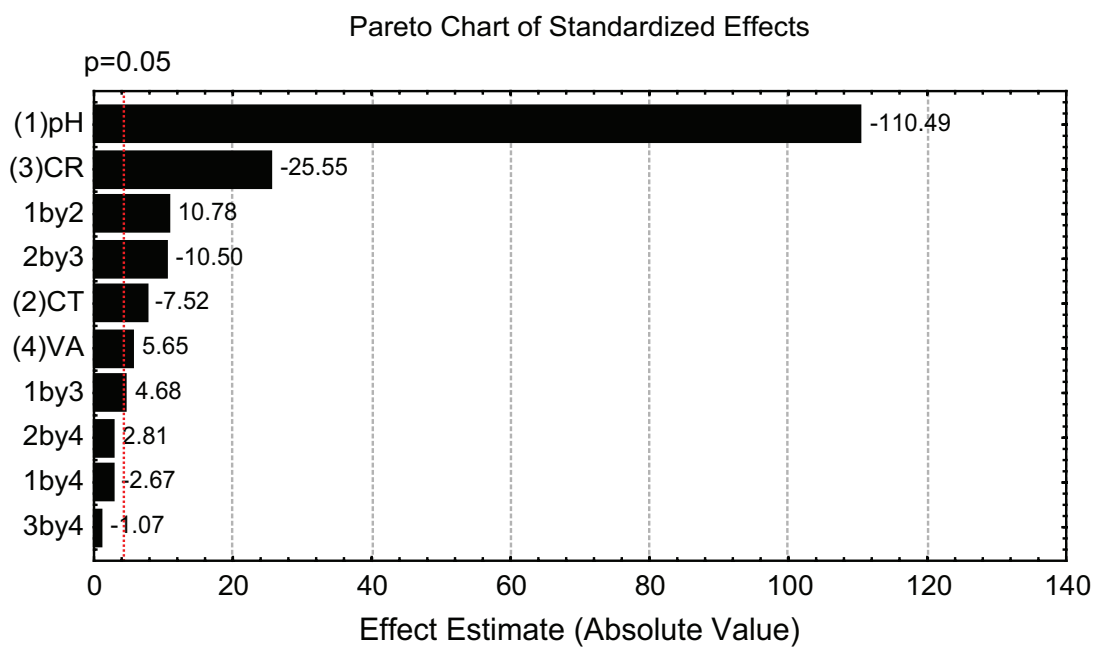

Fig. 3. Pareto Chart for the full factorial design. 
determination. This result demonstrates that the proposed method can be applied for cadmium determination in water samples.

\subsection{Validation process}

The equation of the calibration curve using chemical and operational conditions was given as $A=0.00432+0.00584$ $\left[\mathrm{Cd}^{2+}, \mu \mathrm{g} \mathrm{L}^{-1}\right]$, with $R^{2}=0.9978$, three replicates were used for each concentration $(N=6)$. The equation obtained using direct aspiration in FAAS without the pre-concentration step in the interval of $0.25-1 \mu \mathrm{g} \mathrm{mL}{ }^{-1}$ was $A=0.00368+$ $3.21 .10^{-4}\left[\mathrm{Cd}^{2+}, \mu \mathrm{g} \mathrm{mL}{ }^{-1}\right],(N=6)$. The experimental enrichment factor, calculated as the ratio of the slopes of the calibration graphs with and without pre-concentration, was 18 [20]. The concentration efficiency defined as "preconcentration factor of an analyte achieved by the system per minute" is 14.4 [20].

The precision, expressed as relative standard deviation (RSD), using cadmium solutions of 5 and $25 \mu \mathrm{g} \mathrm{L}^{-1}$, was 2.7 and $2.4 \%$, respectively ( 7 replicates). The detection and quantification limits calculated according to IUPAC recommendation [30] were $0.10 \mu \mathrm{g} \mathrm{L}^{-1}(3 \sigma)$ and $0.33 \mu \mathrm{g} \mathrm{L^{-1 }}(10 \sigma)$. The accuracy was checked by

Table 3

Box-Behnken design with real and coded values

\begin{tabular}{|c|c|c|c|c|}
\hline Replicate & $\mathrm{pH}$ & $\begin{array}{l}\mathrm{BC} \\
\left(\mathrm{mol} \mathrm{L}^{-1}\right)\end{array}$ & $\begin{array}{l}\mathrm{RC} \\
\left(\mathrm{mol} \mathrm{L}^{-1}\right)\end{array}$ & $\begin{array}{l}\text { Response } \\
\text { (Absorbance) }\end{array}$ \\
\hline 1 & $6.5(-1)$ & $0.005(-1)$ & $5 \times 10^{-5}(0)$ & 0.04680 \\
\hline 1 & $8.5(+1)$ & $0.005(-1)$ & $5 \times 10^{-5}(0)$ & 0.04059 \\
\hline 1 & $6.5(-1)$ & $0.015(+1)$ & $5 \times 10^{-5}(0)$ & 0.00837 \\
\hline 1 & $8.5(+1)$ & $0.015(+1)$ & $5 \times 10^{-5}(0)$ & 0.03879 \\
\hline 1 & $6.5(-1)$ & $0.010(0)$ & $1 \times 10^{-5}(-1)$ & 0.01125 \\
\hline 1 & $8.5(+1)$ & $0.010(0)$ & $1 \times 10^{-5}(-1)$ & 0.07137 \\
\hline 1 & $6.5(-1)$ & $0.010(0)$ & $9 \times 10^{-1}(+1)$ & 0.01521 \\
\hline 1 & $8.5(+1)$ & $0.010(0)$ & $9 \times 10^{-1}(+1)$ & 0.03636 \\
\hline 1 & $7.5(0)$ & $0.005(-1)$ & $1 \times 10^{-5}(-1)$ & 0.03285 \\
\hline 1 & $7.5(0)$ & $0.015(+1)$ & $1 \times 10^{-5}(-1)$ & 0.03609 \\
\hline 1 & $7.5(0)$ & $0.005(-1)$ & $9 \times 10^{-1}(+1)$ & 0.02439 \\
\hline 1 & $7.5(0)$ & $0.015(+1)$ & $9 \times 10^{-1}(+1)$ & 0.04995 \\
\hline 1 & $7.5(0)$ & $0.010(0)$ & $5 \times 10^{-5}(0)$ & 0.05094 \\
\hline 1 & $7.5(0)$ & $0.010(0)$ & $5 \times 10^{-5}(0)$ & 0.05301 \\
\hline 1 & $7.5(0)$ & $0.010(0)$ & $5 \times 10^{-5}(0)$ & 0.05697 \\
\hline 2 & $6.5(-1)$ & $0.005(-1)$ & $5 \times 10^{-5}(0)$ & 0.04761 \\
\hline 2 & $8.5(+1)$ & $0.005(-1)$ & $5 \times 10^{-5}(0)$ & 0.04374 \\
\hline 2 & $6.5(-1)$ & $0.015(+1)$ & $5 \times 10^{-5}(0)$ & 0.00738 \\
\hline 2 & $8.5(+1)$ & $0.015(+1)$ & $5 \times 10^{-5}(0)$ & 0.03690 \\
\hline 2 & $6.5(-1)$ & $0.010(0)$ & $1 \times 10^{-5}(-1)$ & 0.01071 \\
\hline 2 & $8.5(+1)$ & $0.010(0)$ & $1 \times 10^{-5}(-1)$ & 0.06768 \\
\hline 2 & $6.5(-1)$ & $0.010(0)$ & $9 \times 10^{-1}(+1)$ & 0.01287 \\
\hline 2 & $8.5(+1)$ & $0.010(0)$ & $9 \times 10^{-1}(+1)$ & 0.03339 \\
\hline 2 & $7.5(0)$ & $0.005(-1)$ & $1 \times 10^{-5}(-1)$ & 0.02808 \\
\hline 2 & $7.5(0)$ & $0.015(+1)$ & $1 \times 10^{-5}(-1)$ & 0.03753 \\
\hline 2 & $7.5(0)$ & $0.005(-1)$ & $9 \times 10^{-1}(+1)$ & 0.02619 \\
\hline 2 & $7.5(0)$ & $0.015(+1)$ & $9 \times 10^{-1}(+1)$ & 0.05184 \\
\hline 2 & $7.5(0)$ & $0.010(0)$ & $5 \times 10^{-5}(0)$ & 0.05364 \\
\hline 2 & $7.5(0)$ & $0.010(0)$ & $5 \times 10^{-5}(0)$ & 0.05436 \\
\hline 2 & $7.5(0)$ & $0.010(0)$ & $5 \times 10^{-5}(0)$ & 0.05301 \\
\hline
\end{tabular}

Table 4

Cadmium determination in drinking water $(N=3)$

\begin{tabular}{llll}
\hline Sample & Cd added $\left(\mu \mathrm{g} \mathrm{L}^{-1}\right)$ & $\mathrm{Cd}^{*}$ found $\left(\mu \mathrm{g} \mathrm{L}^{-1}\right)$ & Recovery $(\%)$ \\
\hline 1 & 0.0 & $0.68 \pm 0.24$ & - \\
& 0.5 & $1.17 \pm 0.67$ & 98 \\
2 & 0.0 & $0.62 \pm 0.20$ & - \\
& 0.5 & $1.09 \pm 0.22$ & 94 \\
3 & 0.0 & $0.38 \pm 0.16$ & - \\
& 0.5 & $0.84 \pm 0.36$ & 92 \\
4 & 0.0 & $0.47 \pm 0.36$ & - \\
& 0.5 & $0.95 \pm 0.18$ & 96 \\
5 & 0.0 & $0.34 \pm 1.7$ & - \\
& 0.5 & $0.86 \pm 0.24$ & 104 \\
\hline
\end{tabular}

$N=$ determination number.

cadmium determination in the standard reference material, NIST SRM 1643d trace elements in natural water, which has a certified value of $6.47 \pm 0.37 \mu \mathrm{g} \mathrm{L}^{-1}$. Using the proposed method the cadmium concentration found in this SRM was $6.08 \pm 1.5 \mu \mathrm{g} \mathrm{L}{ }^{-1}$. The statistical comparison by the $t$-test showed no significant difference between these values.

\subsection{Application-cadmium determination in drinking water samples}

The method was applied for cadmium determination in five drinking water samples. The results are given in Table 4. Addition/recovery tests demonstrate the applicability of this method for the analysis of these samples. The cadmium concentrations were in the range from $0.34-0.68 \mu \mathrm{g} \mathrm{L}^{-1}$. All these results are lower than the permissible maximum level of $5.0 \mu \mathrm{g} \mathrm{L}^{-1}$ given by the Ministry of Health of the Brazilian Government [31].

\section{Conclusions}

The proposed pre-concentration system using a knotted reactor allows cadmium determination in drinking water samples. The method is simple, inexpensive, precise and accurate.

The cadmium content in the drinking water samples collected in Salvador City, Brazil was lower than the permissible maximum level $\left(5.0 \mu \mathrm{g} \mathrm{L}^{-1}\right)$ specified by the World Health Organization.

\section{Acknowledgments}

The authors are grateful to Fundação de Amparo a Pesquisa do Estado da Bahia (FAPESB), Conselho Nacional de Desenvolvimento Científico e Tecnológico (CNPq) and Coordenação de Aperfeiçoamento de Pessoal de Nível Superior (CAPES) for providing grants and fellowships and for financial support. 


\section{References}

[1] M.S. Dopico Garcia, J.M. López, V.R. Bouza, M.J. Abad, E. González Soto, M.V. González Rodríguez, Extraction and quantification of antioxidants from low-density polyethylene by microwave energy and liquid chromatography, Anal. Chim. Acta 521 (2004) $179-188$

[2] M.C.B. Quaresma, R.J. Cassella, M.F.B. Carvalho, R.E. Santelli, Focussed microwave-assisted sample preparation: total phenol determination in petroleum refinery effluents by flow injection spectrophotometry, Microchem. J. 78 (2004) 35-40.

[3] A.C. Ferreira, A.C.S. Costa, M.G.A. Korn, Preliminary evaluation of the cadmium concentration in seawater of the Salvador City, Brazil, Microchem. J. 78 (2004) 77-83.

[4] M.A. Larrea, Y.K. Chang, F.M. Bustos, Effect of some operational extrusion parameters on the constituents of orange pulp, Food Chem. 89 (2005) $301-308$.

[5] D.L. Massart, B.G.M. Vandeginste, L.M.C. Buydens, S. de Jong, P.J. Lewi, J. Smeyers-Verbeke, Handbook of Chemometrics and Qualimetrics Part A, Elsevier, Amsterdam, 2003.

[6] B.B. Neto, I.S. Scarminio, R.E. Bruns, Como fazer Experimentos: Pesquisa e Desenvolvimento na Ciência e na Industria, Editora da UNICAMP, São Paulo, 2001.

[7] S.L.C. Ferreira, W.N.L. dos Santos, C.M. Quintella, B.B. Neto, J.M. Boque-Sendra, Doehlert Matrix: a chemometric toll for analytical chemistry-review, Talanta 63 (2004) 1061-1067.

[8] N. Kannan, A. Rajakumar, G. Rengasamy, Optimisation of process parameters for adsorption of metal ions on straw carbon by using response surface methodology, Environ. Technol. 25 (2004) 513-522.

[9] P. Rana, N. Mohan, C. Rajagopal, Electrochemical removal of chromium from wastewater by using carbon aerogel electrodes, Water Res. 38 (2004) 2811-2820.

[10] G. Annadurai, S.S. Sung, D.J. Lee, Optimisation of floc characteristics for treatment of highly turbid water, Sep. Sci. Technol. 39 (2004) 19-42.

[11] W.N.L. Santos. Aplicação de Matriz de Doehlert na otimização de sistemas de pré-concentração em linha para determinação de zinco e chumbo em águas naturais e efluentes de refinaria de petróleo, PHD Thesis, Universidade Federal da Bahia, Brasil, 2004.

[12] F.H. Walters, H.C. Qiu, The use of a Box-Behnken 3 factor design to study the paper chromatographic-separation of several amino-acid hydroxamates, Anal. Lett. 25 (1992) 1131-1142.

[13] M. Preu, D. Guyot, M. Petz, Development of a gas chromatography mass spectrometry method for the analysis of aminoglycoside antibiotics using experimental design for the optimisation of the derivatisation reactions, J. Chromatogr., A 818 (1998) 95-108.

[14] J.M. Bosque-Sendra, S. Pescarolo, L. Cuadros-Rodriguez, A.M. Garcia-Campana, E.M. Almansa-Lopez, Optimizing analytical methods using sequential response surface methodology. Application to the pararosaniline determination of formaldehyde, Fresenius' J. Anal. Chem. 369 (2001) 715-718.

[15] A. Zougagh, A.G. de Torres, E.V. Alonso, J.M.C. Pavon, Automatic on line preconcentration and determination of lead in water by ICPAES using a TS-microcolumn, Talanta (2004) 503-510.

[16] Y. Liu, S. Mou, Simultaneous determination of trace level bromate and chlorinated haloacetic acids in bottled drinking water by ion chromatography, Microchem. J. 75 (2003) 79-86.

[17] S.M.Z. Al-Kindy, F.O. Suliman, S.B. Salama, A sequential injection method for the determination of aluminum in drinking water using fluorescence enhancement of the aluminum-morin complex in micellar media, Microchem. J. 74 (2003) 173-179.

[18] W.N.L. dos Santos, C.M.M. dos Santos, J.L.O. Costa, H.M.C. Andrade, S.L.C. Ferreira, Multivariate optimization and validation studies in on-line pre-concentration system for lead determination in drinking water and saline waste from oil refinery, Microchem. J. 77 (2004) 123-129.

[19] M.G. Pereira, E.R. Pereira, H. Berndt, M.A.Z. Arruda, Determination of cadmium and lead at low levels by using preconcentration at fullerene coupled to thermospray flame furnace atomic absorption spectrometry, Spectrochim. Acta, Part B: Atom. Spectrosc. 59 (2004) $515-521$

[20] Z. Fang, Flow Injection Separation and Preconcentration, John Wiley, Chichester, 1993.

[21] R.F. Orsi, R.G. Wuilloud, J.C.A. de Wuilloud, R.A. Olsina, L.D. Martinez, On-line preconcentration and determination of cadmium in honey using knotted reactor coupled to flow injection-flame atomic absorption spectrometry, J. AOAC Int. 85 (2002) 1410-1414.

[22] X.P. Yan, Y. Li, Y. Jiang, A flow injection on-line displacement/ sorption preconcentration and separation technique coupled with flame atomic absorption spectrometry for the determination of trace copper in complicated matrices, J. Anal. At. Spectrom. 17 (2002) $610-615$.

[23] R.G. Wuilloud, J.A. Salonia, R.A. Olsina, L.D. Martinez, Determination of vanadium $(\mathrm{V})$ in drinking water by flow injection and preconcentration in a knotted reactor by inductively coupled plasma optical emission spectrometry with ultrasonic nebulization, Spectrochim. Acta, Part B: Atom. Spectrosc. 55 (2000) 671-680.

[24] S. Cerutti, J.A. Salonia, J.A. Gasquez, R.A. Olsina, L.D. Martinez, Determination of scandium in river water by ICP-OES with flowinjection on-line preconcentration using knotted reactor and ultrasonic nebulization, J. Anal. At. Spectrom. 18 (2003) 1198-1201.

[25] W. Som-Aum, S. Liawruangrath, E.H. Hansen, Flow injection on-line preconcentration of low levels of $\mathrm{Cr}(\mathrm{VI})$ with detection by ETAAScomparison of using an open tubular PTFE knotted reactor and a column reactor packed with PTFE beads, Anal. Chim. Acta 463 (2002) 99-109.

[26] S.C. Nielsen, E.H. Hansen, Interfacing flow injection analysis (sequential injection analysis) and electro-thermal atomic absorption spectrometry determination of trace-levels of $\mathrm{Cr}(\mathrm{VI})$ via on-line preconcentration by adsorption in a knotted reactor and by liquid-liquid extraction, Anal. Chim. Acta 422 (2000) 47-62.

[27] J. Wang, E.H. Hansen, On-line sample-pre-treatment schemes for trace-level determinations of metals by coupling flow injection or sequential injection with ICP-MS, TrAC, Trends Anal. Chem. 22 (2003) 836-846.

[28] S. Liawruangrath, W. Som-aum, A. Townshend, A comparison of enrichment factor of knotted and serpentine reactors using flow injection sorption and preconcentration for the off-line determination of some trace elements by inductively coupled plasma mass spectrometry, Talanta 58 (2002) 1177-1184.

[29] Z. Fang, M. Sperling, B. Welz, Flame Atomic Absorption Spectrometric determination of lead in biological samples using a flow injection system with on-line preconcentration by coprecipitation without filtration, J. Anal. At. Spectrom. 6 (1991) 301-306.

[30] IUPAC, Analytical chemistry division, Spectrochim. Acta, Part B: Atom. Spectrosc. 33 (1978) 242.

[31] Ministério de Saúde, Brazil, "Portaria 518” (2004). 